\title{
Aspects Related to Productivity for Four Generations of a Lutzomyia longipalpis Laboratory Colony
}

\section{José Francisco Luitgards-Moura/ ${ }^{+}$, Eloy Guillermo Castellón Bermúdez*, Maria Goreti Rosa-Freitas/**}

\author{
Núcleo Avançado de Vetores, Convênio Fiocruz-UFRR, CCBS Medicina, BR 174 s/nº, 69310-270 Boa Vista, \\ RR, Brasil *Instituto Nacional de Pesquisas da Amazônia, Caixa Postal 478, Manaus, AM, Brasil \\ **Laboratório de Sistemática Bioquímica, Departamento de Bioquímica e Biologia Molecular, Instituto Oswaldo \\ Cruz, Rio de Janeiro, RJ, Brasil
}

A closed colony of Lutzomyia longipalpis was established with specimens collected in the RaposaSerra do Sol indian reservoir, one of the main foci of visceral leishmaniasis in the State of Roraima, Brazil. Biological observations were made on four generations of a $\mathrm{L}$. longipalpis colony with emphasis on productivity. Aspects studied were the number of laid and retained eggs, and the number of adults (male and female) per generation. During the four generations the percentage of engorged females that laid eggs varied from $64.2 \%$ (third generation-F3) to $90.3 \%$ (second generation-F2). The mean number of eggs laid per female varied from 23.6 (F3) to 39.9 (first generation-F1). The maximum number of eggs laid per female varied from $84(F 3)$ to $124(F 1)$. The mean number of retained eggs per female was 12.7 (parental generation-P and F1) to 22.1 (F2). The number of females exceeded the number of males in all generations. However, significant difference for male/female ratio was found only for F3. Fecundity rates were between 42.1 (F3) and 58.3 (F2). From a total of 439 blood-fedfemales, 355 females laid 12,257 eggs that yield 5,354 adults (2,525 males and 2,829 females) in four generations. F2 presented maximum productivity and fecundity rates.

Key words: Lutzomyia longipalpis colony - egg production - sex ratio - productivity - Roraima

Lutzomyia longipalpis is the main visceral leishmaniasis vector in Brazil (Deane 1956). Because of the need of adults for natural insecticide bioassays (to be shown elsewhere) a L. longipalpis colony was initiated. Colonies of $L$. longipalpis have been successfully established before (Sherlock \& Sherlock 1959, Killick-Kendrick et al. 1977, Ready 1978,1979, Modi \& Tesh 1983, Buescher et al. 1984). L. longipalpis populations from Central and South America show a great polymorphism in behavior, morphology and biochemical characters (Ward et al. 1983, Hamilton et al. 1996, Dujardin et al. 1997, Mukhopadhyay et al. 1998a, b, Dias et al. 1998, Yin et al. 1999). These results either lead L. longipalpis differences to be suspected as due to a complex of cryptic species (Lanzaro et al. 1993, Warburg et al. 1994, Hamilton

\footnotetext{
This work was partially supported by Capes (MSc scholarship to JFLM) and by the State Government of Roraima. ${ }^{+}$Corresponding author. Fax: +55-95-6239074. E-mail: lmoura@mandic.com.br Received 30 October 1999 Accepted 6 December 1999
}

et al. 1996, Dujardin et al. 1997, Yin et al. 1999) or within range of intrapopulational variation (Azevedo 1998, Mutebi et al. 1999). L. longipalpis specimens from Roraima population had not been studied before regarding its productivity in captivity. Roraima presents ecological conditions diverse from the Amazon Region. Savanna accounts for $25 \%$ of the Roraima vegetation (75\% being tropical rain forest) and rainfall regimen is opposite to the rest of the Amazon. Specimens were collected in a leishmaniasis focus in Maloca do Napoleão (Raposa - Serra do Sol indian reservoir) where the dry period extends up to eight months per year. Methods used in previous colony establishment, mainly those of Killick-Kendrick et al. (1977) and Ready (1978), were used as guidelines for colonizing L. longipalpis specimens collected at Maloca do Napoleão, Roraima, Brazil. Aspects related to productivity were studied and compared to previous findings. These aspects included mean and maximum number of laid and retained eggs per female and per generation and, sex ratio. Productivity and fecundity were calculated.

\section{MATERIALS AND METHODS}

Seventy nine L. longipalpis females were collected in CDC light traps set from 18:00 to 6:00 h 
during four days in November 1996. These traps were placed in the peridomicile of a house and inside a chicken roost, located in the vicinity of a dam, in a place known as Maloca do Napoleão. This endemic visceral leishmaniasis area is located in the Normandia municipality $\left(03^{\circ} 52^{\prime} 52^{\prime} \mathrm{N}\right.$, $59^{\circ} 37^{\prime} 22$ 'W, $100 \mathrm{~m}$ ), Roraima, Brazil. The region is formed by savanna, with a tropical humid climate and maximum rainfall of 1,600 $\mathrm{mm}$ in June (Ministério das Minas e Energia 1975). Local population is mainly formed by Macuxi indians. CDC trapped phlebotomines were transferred to nylon cages $\left(22 \mathrm{~cm}^{3}\right)$ and blood-fed on a hamster. Engorged females were transported in screw-cap plastic pots (Nalgene $11 \mathrm{~cm} \times 7 \mathrm{~cm}$ height, $500 \mathrm{ml}$ capacity), modified. These modifications consisted in cutting off two circles of $9.5 \mathrm{~cm}$ diameter from the cap and the bottom. The cap when closed hold a $20 \mathrm{~cm}^{2}$ piece of nylon gauze. The bottom was replaced by pouring freshly prepared plaster up to $2 \mathrm{~cm}$ height. After the bottom was dried, plaster was poured on the sides of the pot. Pots containing collected phlebotomines were closed in plastic bags with cotton wool and ice, inside a polystyrene box until arrival in the insectary in Manaus, State of Amazonas. A slice of apple was placed on the top of the nylon gauze. Phlebotomine females were identified according to taxonomic keys (Ryan 1986). Rearing procedures followed KillickKendrick (1987) with a few modifications. The modifications introduced were the substitution of filter paper for sterilized sand inside snap-cap plastic boxes for maintenance of humidity level and the change of sucrose solution for apple slices as additional food source for the adults. Females were blood-fed four days after emergence in anesthetized hamsters. Thionembutal given intraperitoneally was the anesthetic used. Dose varied from $0.4 \mathrm{mg} / 10 \mathrm{~g}$ hamster body weight to $15 \mathrm{mg} / 10 \mathrm{~g}$ body weight, as tolerance increased. Engorged females were individually transferred to $30 \mathrm{ml}$ glass vials with a piece of wet filter paper to lay eggs. Labels containing dates of blood meal, oviposition and death were placed in those vials. Colony was maintained in the facilities of the Leishmaniasis Laboratory (Coordenação de Pesquisas em Ciências da Saúde, Instituto Nacional de Pesquisas da Amazônia, INPA, Manaus). Insectary temperature and humidity were kept at $25-28^{\circ} \mathrm{C}$ and 75 $80 \%$, respectively. Data presented refers to November 1996-October 1997, when the colony reached the fourth generation (F4). After blood meal, slices of apple were placed on the nylon gauze and changed every day. Egg production was verified daily. Eggs were counted and separated in plaster lined plastic pots (Nalgene $11 \mathrm{~cm} \times 7 \mathrm{~cm}$ height, $500 \mathrm{ml}$ capacity) to develop to larvae and pupae.
Larvae of all stages were daily fed with a 1:1 mixture of ground and sieved rabbit food and rabbit feces (Modi \& Tesh 1983) kept at $-40^{\circ} \mathrm{C}$. Pots had their plaster lining changed after one week without adult emergency observation. The plaster change aimed to avoid fungal and mite contamination. Pots were kept in closed 20 × $20 \mathrm{~cm}$ snapcap plastic boxes with sterilized sand to maintain the humidity, and avoid mite infestation. After oviposition, females were dissected for observation of the number of eggs retained in their ovaries. The number of male and female adults emerged were counted daily and transferred to nylon cages. These cages were tightly closed in plastic bags with a wet cotton-wool ball inside. A dark cloth was placed around plastic bags to maintain adults in dark conditions. Adult emergence was checked at 7:00 h and 19:00 h daily. Fecundity rate for each generation was determined by dividing the total number of eggs (laid plus retained) by the number of females. Productivity was calculated by dividing the number of adults (males and females) by the number of eggs laid (x 100) for each generation. Statistical analysis used Statigraphics v. 5.01 and Systat v. 5.01 software programs.

\section{RESULTS}

Males caught in Normandia, Roraima, presented a one-spot phenotype, i.e., tergite IV with paired pale patches of pheromone glands (Ward et al. 1983). Adults copulated 1 to 2 days after emergence irrespective of females being blood-fed. Oviposition occurred from 6 to 13 days after females were blood-fed on a hamster (data not shown). Females readily fed on hamsters in either dark or light conditions. The percentage of bloodfed females that laid eggs varied from $64.2 \%$ (in the third generation-F3) to $90.3 \%$ (second generation-F2, Table I). The great majority of females died after $24 \mathrm{~h}$ after oviposition (data not shown). No females were blood-fed a second time. Fungicides have been used in sand flies colonies for the control of fungus contamination (Hertig \& Johnson 1961, Schmidt 1964). However, mite and fungal contaminations were reduced by a few measures, as changing plaster every time larvae reached adult stage, by maintaining larval food in freezer $\left(-40^{\circ} \mathrm{C}\right)$ and by flaming rearing tools. Even though not quantified, it was observed that males emerged 23 days before females. Adult emergence, also not quantified, occurred mainly at the morning checking time $(7: 00 \mathrm{~h})$. The mean number of eggs laid per female was $23.6( \pm 26.3)$ for F3 to $39.9( \pm 27.5)$ for F1 (Table I). The number of eggs laid by females in the parental generation-P is unknown, as previous oviposition may have occurred prior to collection. For the same reason, the total number 
of eggs, the number of males and females yield, fecundity and productivity rates could not be obtained for P. The maximum number of eggs laid per female varied from 84 in the F3 to 124 in the first generation-F1 (Table I). The number of eggs laid per generation was in the range of 2,236 (F3) to 3,919 (F1, Table I). The mean number of retained eggs varied between $12.7( \pm 14.9$-P and \pm 18.9-F1) and 22.1 ( $\pm 24.0-\mathrm{F} 2$, Table II). The maximum number of retained eggs per female was 62 for $\mathrm{P}$ to 78 in the F2 (Table II). The number of retained eggs per generation varied from 950 (fourth generation-F4) to 2,059 (F2, Table II). Total number of eggs produced (laid plus retained) per generation varied from 3,687 (F4) to 5,424 (F2, Table III). Kruskall-Wallis and Dunn statistical tests showed that there was a significant difference $(p<0.001)$ for the mean number of laid eggs, for the mean number of retained eggs and, for total eggs produced among the four generations. In relation to fecundity, rates were from 42.1 (F3) to 58.3 (F2, Table IV). When accounted together the four generations exhibited a fecundity rate of 41.6 (Table IV). A total of 79 parental generation females yield in captivity 395 males and 432 females in the $\mathrm{F} 1$ generation $(0.91 \mathrm{male} / \mathrm{female}$ ratio, Table $\mathrm{V}$ ). Male/female ratio varied from 0.79 (F3) to 0.96 (F4, Table V). Statistical tests showed a significant difference in the male/female ratio only for $\mathrm{F} 3(\mathrm{p}<0.001$, Table $\mathrm{V})$. $\mathrm{F} 2$ produced the maximum number of males $(1,105)$ and females $(1,179)$ from 3,365 eggs laid by 84 females, presenting the highest productivity $(67.9 \%$, Table V). F1 showed the poorest productivity $21.1 \%$, with 395 males and 432 females emerged from 3,919 eggs laid by 86 females (Table V). For a total of 12,257 eggs laid from 355 females in four generations of $L$. longipalpis, 5,354 adults emerged (2,525 males and 2,829 females) with an overall productivity of $43.7 \%$ (Table V). A summary of the results is given in Table VI. A total of 18, 283 eggs (12,257 laid eggs and 7,037 retained eggs) was obtained during four generations of $L$. longipalpis in captivity (Table VI).

\section{TABLE I}

Number of blood-fed females, number and percentage of egg-laying females, mean and maximum number of eggs laid per female and, number of eggs laid per generation in four generations of Lutzomyia longipalpis in captivity

\begin{tabular}{lcccccc}
\hline Generation & $\begin{array}{c}\text { No. of } \\
\text { blood-fed } \\
\text { females }\end{array}$ & $\begin{array}{c}\text { No. of egg- } \\
\text { laying females } \\
(\%)\end{array}$ & $\begin{array}{c}\text { Mean no. of } \\
\text { eggs laid per } \\
\text { female (SD) }\end{array}$ & $\begin{array}{c}\text { Standard } \\
\text { error }\end{array}$ & $\begin{array}{c}\text { Maximum } \\
\text { no. of eggs laid } \\
\text { per female }\end{array}$ & $\begin{array}{c}\text { No. of laid } \\
\text { eggs per } \\
\text { generation }\end{array}$ \\
\hline P & 79 & $65(82.3 \%)$ & unknown & - & unknown & unknown \\
F1 & 98 & $86(87.7 \%)$ & $39.9( \pm 27.5)$ & 2.7 & 124 & 3919 \\
F2 & 93 & $84(90.3 \%)$ & $36.2( \pm 26.3)$ & 2.7 & 94 & 3365 \\
F3 & 95 & $61(64.2 \%)$ & $23.6( \pm 26.3)$ & 2.6 & 84 & 2236 \\
F4 & 74 & $59(79.7 \%)$ & $37.0( \pm 29.9)$ & 3.4 & 86 & 2737 \\
\hline Total & 439 & $355(80.8 \%)$ & - & - & - & 12257
\end{tabular}

P: parental generation; F1 to F4: first to fourth generation, SD: standard deviation.

\section{TABLE II}

Number of blood-fed females, mean and maximum number of retained eggs per female and number of eggs retained per generation for four generations of Lutzomyia longipalpis in captivity

\begin{tabular}{lccccc}
\hline Generation & $\begin{array}{c}\text { No. of } \\
\text { blood-fed } \\
\text { females }\end{array}$ & $\begin{array}{c}\text { Mean no. of } \\
\text { retained eggs per } \\
\text { female (SD) }\end{array}$ & $\begin{array}{c}\text { Standard } \\
\text { error }\end{array}$ & $\begin{array}{c}\text { Maximum no. } \\
\text { of retained eggs } \\
\text { per female }\end{array}$ & $\begin{array}{c}\text { No. of retained } \\
\text { eggs per } \\
\text { generation }\end{array}$ \\
\hline P & 79 & $12.7( \pm 14.9)$ & 1.9 & 62 & 1011 \\
F1 & 98 & $12.7( \pm 18.9)$ & 1.9 & 70 & 1252 \\
F2 & 93 & $22.1( \pm 24.0)$ & 2.4 & 78 & 2059 \\
F3 & 95 & $18.6( \pm 17.0)$ & 1.7 & 63 & 950 \\
F4 & 74 & $12.8( \pm 15.6)$ & 1.8 & 50 & 7037 \\
\hline Total & 439 & - & - & - & \\
\hline
\end{tabular}

P: parental generation; F1 to F4: first to fourth generation; SD: standard deviation. 


\section{TABLE III}

Number of blood-fed females, mean and maximum numbers of eggs laid and retained per female and per generation and, total of eggs produced (laid plus retained) during four generations of Lutzomyia longipalpis in captivity

\begin{tabular}{lccccccc}
\hline Generation & $\begin{array}{c}\text { No. of } \\
\text { blood-fed } \\
\text { females }\end{array}$ & \multicolumn{2}{c}{$\begin{array}{c}\text { Maximum no. of eggs } \\
\text { per female }\end{array}$} & & \multicolumn{2}{c}{$\begin{array}{c}\text { No. of eggs per } \\
\text { generation }\end{array}$} & \multirow{2}{*}{$\begin{array}{c}\text { Total no. of } \\
\text { eggs per } \\
\text { generation }\end{array}$} \\
\cline { 3 - 4 } & & Laid & Retained & & Laid & Retained & \\
\hline P & 79 & unknown & 62 & & unknown & 1011 & unknown \\
F1 & 98 & 124 & 70 & & 3919 & 1252 & 5171 \\
F2 & 93 & 94 & 78 & & 3365 & 2059 & 5424 \\
F3 & 95 & 84 & 63 & & 2236 & 1765 & 4001 \\
F4 & 74 & 86 & 50 & & 2737 & 950 & 3687 \\
\hline
\end{tabular}

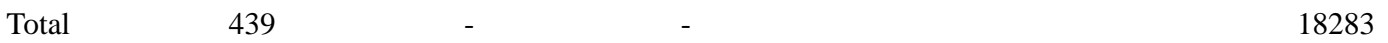

P: parental generation; F1 to F4: first to fourth generation; SD: standard deviation; total number of eggs is laid plus retained eggs.

TABLE IV

Number of blood-fed females, number of eggs laid and retained per generation, total number of eggs, and fecundity rate for four generations of Lutzomyia longipalpis in captivity

\begin{tabular}{lccccc}
\hline Generation & $\begin{array}{c}\text { No. of blood- } \\
\text { fed females }\end{array}$ & $\begin{array}{c}\text { No. of laid eggs } \\
\text { per generation }\end{array}$ & $\begin{array}{c}\text { No. of retained eggs } \\
\text { per generation }\end{array}$ & $\begin{array}{c}\text { Total no. of eggs } \\
\text { per generation }\end{array}$ & $\begin{array}{c}\text { Fecundity } \\
\text { rate }\end{array}$ \\
\hline P & 79 & unknown & 1011 & unknown & unknown \\
F1 & 98 & 3919 & 1252 & 5171 & 52.8 \\
F2 & 93 & 3365 & 2059 & 5424 & 58.3 \\
F3 & 95 & 2236 & 1765 & 4001 & 42.1 \\
F4 & 74 & 2737 & 950 & 3687 & 49.8 \\
\hline Total & 439 & 12257 & 6026 & 18283 & 41.6 \\
\hline
\end{tabular}

P: parental generation; F1 to F4: first to fourth generation; fecundity rate is the total number of eggs (laid plus retained) divided by the number of blood-fed females.

TABLE V

Number of egg-laying females, number of laid eggs per generation, number of resulting males and females and productivity (in percentage) for four generations of Lutzomyia longipalpis in captivity

\begin{tabular}{|c|c|c|c|c|c|c|c|c|}
\hline \multirow[t]{2}{*}{ Generation } & \multirow{2}{*}{$\begin{array}{l}\text { No. of } \\
\text { egg-laying } \\
\text { females }\end{array}$} & \multirow{2}{*}{$\begin{array}{l}\text { No. of laid } \\
\text { eggs per } \\
\text { generation }\end{array}$} & \multicolumn{2}{|c|}{ Resulting } & \multirow{2}{*}{$\begin{array}{l}\text { Male/female } \\
\text { ratio }\end{array}$} & \multirow{2}{*}{$\begin{array}{c}\chi^{2} \\
\text { (level of } \\
\text { significance) }\end{array}$} & \multirow{2}{*}{$\begin{array}{c}\text { No. } \\
\text { of } \\
\text { adults }\end{array}$} & \multirow{2}{*}{$\begin{array}{c}\text { Productivity } \\
(\%)\end{array}$} \\
\hline & & & Males & Females & & & & \\
\hline $\mathrm{P}$ & 65 & unknown & unknown & unknown & unknown & - & unknown & unknown \\
\hline $\mathrm{F} 1$ & 86 & 3919 & 395 & 432 & 0.91 & $1.66(>0.05)$ & 827 & 21.1 \\
\hline $\mathrm{F} 2$ & 84 & 3365 & 1105 & 1179 & 0.94 & $2.40(>0.05)$ & 2284 & 67.9 \\
\hline F3 & 61 & 2236 & 653 & 831 & 0.79 & $21.40(<0.001)$ & 1484 & 66.4 \\
\hline $\mathrm{F} 4$ & 59 & 2737 & 372 & 387 & 0.96 & $0.30(>0.05)$ & 759 & 27.7 \\
\hline Total & 439 & 12257 & 2525 & 2829 & 0.90 & - & 5354 & 43.7 \\
\hline
\end{tabular}

P: parental generation; F1 to F4: first to fourth generation; SD: standard deviation; $\chi 2$ and level of significance $\mathrm{p}$ for the difference between the number of males and females; productivity is the number of adults (males and females) divided by the number of laid eggs (times 100). 
TABLE VI

Summary of productivity aspects observed for four generations of Lutzomyia longipalpis in captivity

\begin{tabular}{lcccccc}
\hline Aspect & Parental & F1 & F2 & F3 & F4 & Total \\
\hline No. of blood-fed females & 79 & 98 & 93 & 95 & 74 & 439 \\
No. of egg-laying females & 65 & 86 & 84 & 61 & 59 & 355 \\
(\% of blood-fed) & $(82.3 \%)$ & $(87.7 \%)$ & $(90.3 \%)$ & $(64.2 \%)$ & $(79.7 \%)$ & $(80.8 \%)$ \\
Mean no. of eggs laid per female & unknown & 39.9 & 36.2 & 23.6 & 37.0 & - \\
(SD) & & $( \pm 27.5)$ & $( \pm 26.3)$ & $( \pm 26.3)$ & $( \pm 29.9)$ & \\
Maximum no. of eggs laid per female & unknown & 124 & 94 & 84 & 86 & - \\
No. of eggs laid per generation & unknown & 3919 & 3365 & 2236 & 2737 & 12257 \\
Mean no. of retained eggs per female & 12.7 & 12.7 & 22.1 & 18.6 & 12.8 & - \\
(SD) & $( \pm 14.9)$ & $( \pm 18.9)$ & $( \pm 24.0)$ & $( \pm 17.0)$ & $( \pm 15.6)$ & - \\
Maximum no. of retained eggs per female & 62 & 70 & 78 & 63 & 50 & 7037 \\
No. of retained eggs per generation & 1011 & 1252 & 2059 & 1765 & 950 & 78283 \\
Total no. of eggs (laid plus retained) & unknown & 5171 & 5424 & 4001 & 3687 & 1828 \\
Male/female & unknown & $395 / 432$ & $1105 / 1179$ & $653 / 831$ & $372 / 387$ & $2525 / 2829$ \\
(Ratio) & & $(0.91)$ & $(0.94)$ & $(0.79)$ & $(0.96)$ & $(0.90)$ \\
No. of adults (males plus females) & unknown & 827 & 2284 & 1484 & 759 & 5354 \\
Fecundity rate & unknown & 52.8 & 58.3 & 42.1 & 49.8 & 41.6 \\
Productivity (\%) & unknown & 21.1 & 67.9 & 66.4 & 27.7 & 43.7 \\
\hline
\end{tabular}

SD: standard deviation; productivity is the number of adults emerged (males and females) divided by the number of laid eggs (times 100); fecundity rate is the total number of eggs (laid plus retained) divided by the number of bloodfed females.

\section{DISCUSSION}

L. longipalpis has long been recognized as the main visceral leishmaniasis vector in Brazil (Deane 1956). A L. longipalpis colony was initiated for natural insecticide bioassays (to be shown elsewhere) with plants and insects collected in Roraima, a State in the Brazilian Amazon. Methods used for previous $L$. longipalpis colonies were used aiming to achieve maximum productivity (Killick-Kendrick et al. 1977). L. longipalpis specimens from Roraima population have not been studied before regarding its productivity in captivity. Roraima presents ecological conditions diverse from the Amazon Region, regarding vegetation (25\% savanna and $75 \%$ tropical rain forest) and rain fall regimen (opposite to the rest of the Amazon) that could account for differences in the local population. Specimens were collected in a leishmaniasis focus in Maloca do Napoleão (Raposa Serra do Sol indian reservoir). The aspects studied were the mean and maximum number of laid and retained eggs per female and per generation and, sex ratio for four generations of L. longipalpis in captivity. Based on these results, productivity and fecundity were calculated.

Even though morphological analysis was not aimed, it could be observed that males from this population were the one-spot phenotype (Ward et al. 1983). Variability in tergal spot morphology is believed to be a polymorphic character not related to genetic isolation (Mukhopadhyay et al. 1998a).

Time between blood meal and oviposition varied from 6-13 days (data not shown). Previous works report a variation from 2 to 7 days (Sherlock $\&$ Sherlock 1972) and 4 to 9 days (Killick-Kendrick et al. 1977).

Males emerged two days before females (data not shown). After this period, male/female ratio was bigger for females (Table VI). Early male emergence has been observed for many insects. It has been long known the male genitalia of some insects undergoes a $180^{\circ}$ rotation after emergence (Clements 1992 for review on Culicidae). The $180^{\circ}$ male genitalia rotation and late female emergence (2-3 days after male emergence) seem to be linked. Genitalia rotation is necessary for male to become sexually mature. When females emerge, males are ready for copulating. Time for pheromone production may also account for time emergence discrepancy between males and females. As many as four days are necessary for pheromone production to be maximum in males and a threshold level might be necessary to attract females (Hamilton et al. 1994). Also pheromone production may help sclerotization of the aedeagus. 
Combined extract of rabbit food, rabbit feces and larval rearing media showed to have a synergetic effect on sandfly egg laying (Elnaiem \& Ward 1992). Nonetheless we opted for not only cleaning the pots but also change the plaster as mite and fungus were a problem for colony establishment.

Adults were checked for emergence at 7:00 h and 19:00 h, daily. Adults were more abundant at the 7:00 h checking time, indicating a preference for night/early morning emergence. The cool and moist time near dawn is long known to be the time of choice for emergence for most insects (Pittendrigh 1957). However, an hourly checking should have been done to accurately determine that night was the preferential emergence time.

The difference for sex ratio emergence in the four generations with predominance of females may be due to fluctuations on genes that alter sexual proportion. These fluctuations might be natural oscillations or the beginning of a gene fixation (Cazemajor et al. 1997, Owusu-Daaku et al. 1997 for Aedes aegypti). Killick-Kendrick et al. (1977) observed a ratio of males to females of 1.2:1.0 for L. longipalpis (Lapinha strain).

The fact that almost all females died within $24 \mathrm{~h}$ of oviposition has been observed before (KillickKendrick et al. 1977, Buescher et al. 1984, Elnaiem \& Ward 1992).

Souza et al. (1995) state that optimal conditions of laboratory maintenance relate to both sugar and blood feeding. In fact, Brazil and Ward (1989) suggest that $L$. longipalpis females lay more eggs when they receive sucrose. Size and composition of blood meal also affect egg laying (Ready 1979). Females were fed to completion in hamsters and slices of apple were their source of sugar.

Females laid an average of $23.6(\mathrm{~F} 3)$ to 39.9 (F1) eggs per oviposition (Table VI). This is in accordance to previous findings of 30.1 eggs per oviposition (mean, Sherlock \& Sherlock 1959). The mean and maximum number of eggs laid per female, males and females produced, fecundity and productivity in the parental generation could not be obtained, as parental females age and parity status in the field prior to collection are unknown.

Fecundity and productivity are aspects that aim to indicate the success of a given generation. Nonetheless, this meaning should be used with parsimony. Fecundity rate is related to egg production irrespective of oviposition. A generation is said fecund even if retains eggs produced. Productivity relates to the number of adults emerged from a certain number of eggs laid. Productivity is high even when a small number of laid eggs originate the most amount of adults. For productivity the number of retained eggs is irrelevant.
In spite of having the highest number of retained eggs per female (22.1) and per generation $(2,059)$, F2 had the highest number of eggs produced (5,424 from 84 blood-fed egg-laying females) and the highest adult emergence (2,284 adults out from the 3,365 eggs laid). As a result of these features F2 was the most fecund (58.3) and productive generation $(67.9 \%$, Table VI).

The lowest productive generation F1 retained 1,252 eggs (the third in the four generations), had the highest number of laid eggs per female (39.9) and per generation $(3,919)$ but only 827 emerging adults. Therefore F1 ranked last for productivity (21.1, Table VI), although was the second highest for fecundity $(52.8, \mathrm{~F} 2$ was the highest with 58.3, Table VI).

Generation performance also relates to the individual level. A total of $90.3 \%$ of $\mathrm{F} 2$ females were egg-laying females (the highest percentage, Table VI). F2 also presented the second highest number of eggs laid per female (94 opposed to 124 for F1, Table VI) and in spite of showing the highest number of eggs retained per female (78, Table VI) attained the highest fecundity (58.3) and productivity $(67.9 \%$, Table VI). Even though F1 had the highest number of eggs laid per female (124) and the second least number of retained eggs (70 opposed to 50 for F4, Table VI), had the lowest numbers of emerged adults and the lowest productivity (21.1, Table VI).

A successful generation can be assessed by fecundity and productivity that bring in their definitions the interconnected, interrelated variables (genome of parental founder females, nutrients availability throughout the life cycle, developmental environment) behind a high percentage of bloodfed females able to lay eggs, a large number of laid eggs (irrespective of the number of retained) and a high number of adults emerged.

\section{ACKNOWLEDGEMENTS}

To Rui Alves de Freitas for helping in the taxonomy, Toby Vincent Barrett, Roberto Dualibi Naiff and Raul Guerra de Queiroz for their advisory and Roberto Farias and Silvia Cassia Brandão Justiniano for technical support, Alexandre Afrânio Peixoto for fruitful discussion on insect behavior and two anonymous referees for their invaluable contributions.

\section{REFERENCES}

Azevedo ACR 1998. Estudos Comparativos de Populações de Lutzomyia longipalpis, MSc Thesis, Instituto Oswaldo Cruz, Rio de Janeiro, 120 pp.

Brazil RP, Ward RD 1989. Sugar meals, oviposition and survival in laboratory-bred Lutzomyia longipalpis (Diptera: Psychodidae). Mem Inst Oswaldo Cruz 84: 129.

Buescher MD, Rutledge LC, Roberts J, Nelson JH 1984. 
Observations on multiple feeding by Lutzomyia longipalpis in the laboratory. Mosquito News 44: 7677.

Cazemajor M, Landré C, Montchamp-Moreau C 1997. The sex-ratio trait in Drosophila simulans: genetic analysis of distortion and suppression. Genetics 147 : 635-642.

Clements AN 1992. The Biology of Mosquitoes. Development, Nutrition and Reprodution, Chapman \& Hall, London, 509 pp.

Deane LM 1956. Leishmaniose Visceral no Brasil. Estudos sôbre Reservatórios e Transmissores Realizados no Estado do Ceará, Serv Nac Educ Sanit, Rio de Janeiro, 162 pp.

Dias ES, Fortes-Dias CL, Stiteler JM, Perkins PV, Lawyer PG 1998. Random amplified polymorphic DNA (RAPD) analysis of Lutzomyia longipalpis laboratory colony. Rev Inst Med Trop São Paulo 40: 49-53.

Dujardin JP, Torrez EM, Le Pont F, Hervas D, Sossa D 1997. Isozymic and metric variation in the Lutzomyia longipalpis complex. Med Vet Entomol 11: 394-400.

Elnaiem DA, Ward R. 1992 Oviposition attractants and stimulants for the sandfly Lutzomyia longipalpis (Diptera: Psychodidae). J Med Entomol 29: 5-12.

Hamilton JGC, Dougherty MJ, Ward RD 1994. Isolation and identification of sex pheromone activity in components of tergal gland extract of Lutzomyia longipalpis from Northeast Brazil. J Chem Ecol 20: 141-151.

Hamilton JGC, Ward RD, Dougherty MJ, Maignon R, Ponce C, Ponce E, Noyes H, Zeledon R 1996. Comparison of the sex-pheromone components of Lutzomyia longipalpis (Diptera: Psychodidae) from areas of visceral and atypical cutaneous leishmaniasis in Honduras and Costa Rica. Ann Trop Med Parasitol 90: 533-541.

Hertig M, Johnson PT 1961. The rearing of Phlebotomus sandflies (Diptera: Psychodidae). I. Technique. Ann Ent Soc Amer 54: 753-764.

Killick-Kendrick R. 1987 The Leishmaniasis. In W Peters \& R Killick-Kendrick (eds), Methods for the Study of Phlebotomine Sandflies, London, Academic Press, p. 473-497.

Killick-Kendrick R, Leaney AJ, Ready PD 1977. The establishment maintenance and productivity of a laboratory colony of Lutzomyia longipalpis (Diptera: Psychodidae). J Med Ent 13: 429-440.

Lanzaro GC, Ostovska K, Herrero MV, Lawyer PG, Warburg A 1993. Lutzomyia longipalpis is a species complex: genetic divergence and interspecific hybrid sterility among three populations. Am J Trop Med Hyg 48: 839-847.

Ministério das Minas e Energia 1975. Projeto RADAMBRASIL. Roraima: Geomorfologia, Pedologia, Vegetação e Uso Potencial da Terra, Rio de Janeiro, 428 pp.

Modi GB, Tesh RB 1983. A simple technique for mass rearing Lutzomyia longipalpis and Phlebotomus papatasi (Diptera: Psichodidae) in the laboratory. $J$ Med Entomol 20: 568-569.

Mukhopadhyay J, Ghosh K, Azevedo AC, Rangel EF, Munstermann LE 1998a. Genetic polymorphism of morphological and biochemical characters in a Natal, Brazil population of Lutzomyia longipalpis (Diptera: Psychodidae). J Am Mosq Control Assoc 14: 277-82.

Mukhopadhyay J, Ghosh K, Rangel EF, Munstermann LE 1998b. Genetic variability in biochemical characters of Brazilian field populations of the Leishmania vector, Lutzomyia longipalpis (Diptera: Psychodidae). Am J Trop Med Hyg 59: 893-901.

Mutebi JP, Alexander B, Sherlock I, Wellington J, Souza AA, Shaw J, Rangel EF, Lanzaro GC 1999. Breeding struture of the sand fly Lutzomyia longipalpis (Lutz \& Neiva ) in Brazil. Am J Trop Med Hyg 61: 149-157.

Owusu-Daaku K, Wood RJ, Butler RD 1997. Selected lines of Aedes aegypti with persistently distorted sex ratios. Heredity 79: 388-393.

Pittendrigh CS 1957. Adaptation, Natural Selection, and Behavior. In A Roe \& GG Simpson (eds), Behavior and Evolution, New Haven, Yale University Press, p. 390-416.

Ready PD 1978. The feeding habits of laboratory-bred Lutzomyia longipalpis (Diptera, Psychodidae). J Med Ent 14: 545-552.

Ready PD 1979. Factors affecting egg production of laboratory bred Lutzomyia longipalpis (Diptera: Psychodidae). J Med Ent 16: 413-423.

Ryan L 1986. Flebótomos do Estado do Pará, Brasil, Documento Técnico ${ }^{\circ} 1$, Instituto Evandro Chagas, Belém, 153 pp.

Schmidt ML 1964. Laboratory culture of two Phlebotomus species, P. papatasi and P. orientalis. Bull WHO 31: 577-578.

Sherlock IA, Sherlock VA 1959. Criação e biologia em laboratório do Phlebotomus longipalpis Lutz \& Neiva, 1912 (Diptera Psychodidae). Rev Bras Biol 19: 229-250.

Sherlock IA, Sherlock VA 1972. Métodos práticos para a criação de flebotomíneos em laboratório. Rev Bras Biol 32: 209-217.

Souza NA, Andrade-Coelho CA, Barbosa AF, Vilela ML, Rangel EF, Deane MP 1995.The influence of sugars and amino acids on the blood-feeding behaviour, oviposition and longevity of laboratory colony of Lutzomyia longipalpis (Lutz \& Neiva, 1912) (Diptera: Psychodidae, Phlebotominae). Mem Inst Oswaldo Cruz 90: 751-757.

Warburg A, Saraiva E, Lanzaro GC, Titus RG, Neva F 1994. Saliva of Lutzomyia longipalpis sibling species differs in its composition and capacity to enhance leishmaniasis. Phil Trans Royal Soc London, series $B$, 345: 223-230.

Ward RD, Ribeiro AL, Ready PD, Murtagh A 1983. Reproductive isolation between different forms of Lutzomyia longipalpis (Lutz \& Neiva), (Diptera: Psychodidae), the vector of Leishmania donovani chagasi Cunha \& Chagas and its significance to Kala-zar distribution in South America. Mem Inst Oswaldo Cruz 78: 269-280.

Yin H, Mutebi JP, Marriott S, Lanzaro GC 1999. Metaphase karyotypes and G-banding in sandflies of the Lutzomyia longipalpis complex. Med Vet Entomol 13: 72-77. 